\title{
PEMODELAN PENYEBARAN POLUTAN DI UDARA DENGAN SOLUSI PERSAMAAN DIFUSI ADVEKTIF
}

\author{
Handy I. R. Mosey ${ }^{1)}$ \\ e-mail: handymos@yahoo.com \\ Program Studi Fisika FMIPA Universitas Sam Ratulangi, Manado 95115
}

\begin{abstract}
ABSTRAK
Telah dimodelkan penyebaran konsentrasi polutan di udara akibat emisi pabrik melalui persamaan difusi advektif. Sebagai syarat batas, polutan dianggap berasal dari suatu sumber titik dan penyebaran konsentrasinya dipengaruhi oleh stabilitas atmosfir. Selanjtunya, model diselesaikan dengan bahasa pemrograman MATLAB. Pada kondisi atmosfir stabil, polutan terkonsentrasi pada daerah dengan jarak 27-28 kilometer dari sumber polutan dengan nilai konsentrasi sebesar $3,1 \mathrm{mg} / \mathrm{m}^{3}$. Sedangkan pada kondisi atmosfir netral, konsentrasi polutan maksimum berada pada jarak 2,1 kilometer dari sumber dengan nilai $11 \mathrm{mg} / \mathrm{m}^{3}$. Pada kondisi atmosfir labil, konsentrasi polutan berada pada daerah yang cukup dekat dengan sumber, yaitu 0,6 kilometer dengan nilai $14,55 \mathrm{mg} / \mathrm{m}^{3}$.
\end{abstract}

Kata kunci: advektif, difusi, polutan

\section{MODELING OF AIRBORNE-POLLUTANT SPREADING USING THE SOLUTION OF ADVECTIVE-DIFFUSION EQUATION}

\begin{abstract}
The spreading of airbone-pollutant concentration that was resulted from factory effluent was modelled using advective-diffusion equation. In this modelling, it was considered that airbonepollutant was resulted from a stationary point source and its spreading was affected by atmospheric stability. Model was completed by MATLAB programming. When atmosphere was stable, the pollutant was concentrated at $27-28 \mathrm{~km}$ distance from the source concentration 3,1 $\mathrm{mg} / \mathrm{m}^{3}$. The maximum concentration of pollutant was $11 \mathrm{mg} / \mathrm{m}^{3}$ at $2,1 \mathrm{~km}$ distance under neutral atmosphere condition. The pollutant was concentrated at $0,6 \mathrm{~km}$ with magnitude $14,55 \mathrm{mg} / \mathrm{m}^{3}$ if the atmosphere was unstable.
\end{abstract}

Keywords: advection, diffusion, pollutant

\section{PENDAHULUAN}

Pesatnya laju pertumbuhan dunia industri baik nasional maupun internasional telah mengakibatkan meningkatnya pencemaran udara di daerah lokasi industri, bahkan di daerah yang berada di sekitar lokasi tersebut. Pengetahuan tentang kajian meteorologi yakni angin dan kestabilan udara di daerah sekitar lokasi industri sangat penting sebelum dibangunnya sebuah pabrik.

Penyebaran polutan di udara akibat emisi asap pabrik dapat dikaji secara fisis dengan asumsi bahwa penyebaran materi dalam suatu media berlangsung selama belum tercapainya kesetimbangan mekanik. Proses ini dikenal dengan nama proses difusi. Kenyataannya bahwa penyebaran polutan di udara juga dipengaruhi oleh faktor meteorologi yakni angin dan kestabilan udara. Angin menyebabkan terjadinya proses adveksi, sedangkan kestabilan udara (gradien suhu secara vertikal) mengakibatkan perbedaan pola kepulan asap yang bergerak meninggalkan cerobong.

Berdasarkan hal di atas dapat dibuat suatu model analitik untuk penyebaran dan konsentrasi polutan di udara yang bersumber dari cerobong asap pabrik. Hasil penelitian ini diharapkan dapat digunakan sebagai salah satu bahan pertimbangan atau acuan dalam perencanaan pembangunan lokasi pabrik. 


\section{Persamaan Difusi-Advektif}

Fenomena transport dalam fluida atau zat alir (zalir) dapat terjadi melalui kombinasi antara proses difusi dan adveksi. Persamaan difusi advektif dapat di tuliskan,

$\frac{\partial \mathrm{C}}{\partial t}+\nabla \cdot(\boldsymbol{u} \mathrm{C})=K \nabla^{2} \mathrm{C}$

Solusi untuk persamaan (1) dicari dengan menggunakan metode pemisahan peubah, metode similaritas, transformasi Laplace dan metode Wronskian. Didapatkan solusi untuk sumber polutan yang kontinu,

$\mathrm{C}(x, y, z)=\frac{q}{2 \pi \sigma_{x} \sigma_{y} \sigma_{z}}\left[\exp \left\{-\frac{y^{2}}{2 \sigma_{y}^{2}}-\frac{(z-h)^{2}}{2 \sigma_{z}^{2}}\right\}+\right.$
$\left.\exp \left\{-\frac{y^{2}}{2 \sigma_{y}^{2}}-\frac{(z+h)^{2}}{2 \sigma_{z}^{2}}\right\}\right]$

Dengan, $\mathrm{C}$ adalah konsentrasi, $\mathrm{q}$ adalah emisi Cerobong, $\mathrm{h}$ adalah tinggi Cerobong, $\sigma_{\mathrm{x}, \mathrm{y}, \mathrm{z}}$ adalah koefisien penyebaran plume (asap yang keluar dari Cerobong).

\section{METODOLOGI PENELITIAN}

Model penyebaran polutan di udara dibuat dengan asumsi bahwa tanah di sekitar cerobong adalah datar (tidak ada perubahan ketinggian) dan konsentrasi di permukaan tanah (pada $\mathrm{z}=0$ ), dan kestabilan atmosfir pada tiga kondisi, yakni: stabil, netral dan labil.

Pemodelan dilakukan dengan memisalkan debit emisi cerobong (q) sebesar $5 \mathrm{~kg} / \mathrm{s}$, tinggi cerobong 50 meter dan kecepatan angin dianggap konstan sebesar 5 $\mathrm{m} / \mathrm{s}$. Setelah itu, disimulasikan dalam bahasa pemrograman MATLAB.

\section{HASIL DAN PEMBAHASAN}

Berdasarkan simulasi komputer hasil yang didapat bahwa konsentrasi polutan disekitar cerobong sangat dipengaruhi oleh kondisi atmosfir. Pada kondisi atmosfir stabil penyebaran polutannya lebih landai daripada kondisi atmosfir netral, sedangkan untuk kondisi atmosfir labil profil penyebaran polutan lebih curam dan garis konturnya berbentuk lebih memanjang yang berarti pula bahwa pada kondisi ini penyebaran polutan dominan mengikuti arah angin.
Pada kondisi atmosfir stabil, polutan terkonsentrasi pada daerah dengan jarak 27$28 \mathrm{~km}$ dari sumber (cerobong) dengan nilai konsentrasi sebesar $3,1 \mathrm{mg} / \mathrm{m}^{3}$. Pada kondisi atmosfir netral, polutan maksimum berada pada jarak $2100 \mathrm{~m}$ dari sumber dengan nilai $11 \mathrm{mg} / \mathrm{m}^{3}$, sedangkan untuk kondisi atmosfir labil konsentrasi polutan berada pada daerah yang cukup dekat dengan sumber yaitu pada jarak $600 \mathrm{~m}$ dengan nilai konsentrasi 14,55 $\mathrm{mg} / \mathrm{m}^{3}$.

Untuk melihat sejauh mana pengaruh emisi awal polutan dan kecepatan angin terhadap pola konsentrasi pada kondisi atmosfir labil, maka telah dilakukan pemasukan data q (emisi awal) dan u (kecepatan angin) yang bervariasi diperoleh hasil bahwa semakin besar emisi awal polutan maka semakin tinggi konsentrasi maksimum polutan namun posisi (jarak dari sumber) daerah terjadinya konsentrasi maksimum adalah tetap. Untuk profil penyebaran polutan dengan emisi yang sama memperlihatkan bahwa semakin kecil kecepatan angin maka semakin kecil pula nilai konsentrasi maksimumnya disertai dengan semakin jauhnya posisi daerah konsentrasi maksimum dari sumber dan semakin landainya kurva. Namun pada kasus ini terlihat juga bahwa kecepatan angin di atas $5 \mathrm{~m} / \mathrm{s}$ telah mengakibatkan menurunnya konsentrasi maksimum dari polutan.

Hal ini terjadi karena kecepatan angin yang kecil menyebabkan tingginya kenaikan plume yang berdampak pada semakin jauhnya daerah konsentrasi maksimum dari sumber polutan. Sebaliknya angin yang makin cepat menyebabkan kenaikan plume yang semakin kecil sehingga daerah terbentuknya konsentrasi maksimum berada semakin dekat dengan sumber dan pada kondisi tertentu konsentrasi maksimumnya akan semakin menurun karena proses percampuran dengan udara yang semakin tinggi.

Untuk keadaan atmosfir yang diinginkan agar pencemaran terhadap lingkungan dapat diminimalisir yakni keadaan atmosfir yang labil, karena semakin jauh jarak dengan sumber maka semakin rendah konsentrasi. Atau bisa juga dengan tinggi cerobong asap yang dibuat semakin tinggi. 


\section{KESIMPULAN}

1. Solusi persamaan difusi advektif yang menggambarkan proses penyebaran konsentrasi dapat diselesaikan dengan menggunakan metode pemisahan peubah. Dalam hal ini solusi untuk nilai konsentrasi sebagai fungsi dalam arah $\mathrm{x}$ dan arah y diselesaikan dengan metode similaritas yaitu metode yang dapat mengubah persamaan diferensial parsial menjadi persamaan diferensial biasa, sedangkan penyebaran dalam arah $\mathrm{Z}$ digunakan transformasi Laplace.

2. Model penyebaran polutan di udara dapat dibuat berdasarkan solusi persamaan difusi advektif dengan syarat batas kestabilan udara suatu daerah dan perhitungannya dapat dilakukan dengan memanfaatkan bahasa pemrograman MATLAB.

3. Hasil yang diperoleh menunjukan bahwa dari input yang sama $(\mathrm{h}=50 \mathrm{~m}, \mathrm{q}=5$ $\mathrm{kg} / \mathrm{s}, \mathrm{u}=5 \mathrm{~m} / \mathrm{s}$ ) potensi pencemaran berdasarkan tingginya konsentrasi polutan jika dimulai dari nilai konsentrasi tertinggi berturut-turut adalah kondisi labil, netral kemudian stabil. Jarak dari sumber ke posisi yang memiliki konsentrasi polutan maksimum mulai dari yang terdekat adalah kondisi labil, netral kemudian stabil. Sementara luas daerah dengan konsentrasi yang sama mulai dari yang terbesar adalah kondisi stabil, netral, kemudian labil.

4. Pada kondisi atmosfir stabil, polutan terkonsentrasi pada daerah dengan jarak 27-28 km dari sumber dengan nilai konsentrasi sebesar $3,1 \mathrm{mg} / \mathrm{m}^{3}$. Sedangkan pada kondisi atmosfir netral, konsentrasi polutan maksimum berada pada jarak 2,1 $\mathrm{km}$ dari sumber dengan nilai $11 \mathrm{mg} / \mathrm{m}^{3}$, dan untuk kondisi atmosfir labil, konsentrasi tertinggi polutan berada pada daerah yang cukup dekat dengan sumber yaitu pada jarak $0,600 \mathrm{~km}$ dengan nilai $14,55 \mathrm{mg} / \mathrm{m}^{3}$.

5. Variasi input nilai emisi awal polutan pada suatu kondisi atmosfir hanya meningkatkan konsentrasi maksimum polutan pada suatu daerah tanpa perubahan posisi dari lokasi terjadinya. Sedangkan variasi input kecepatan angin menunjukan adanya variasi konsentrasi maksimum dan lokasi terjadinya.
Kecepatan angin yang semakin tinggi meningkatkan nilai konsentrasi maksimum polutan namun pada tingkat kecepatan angin tertentu justru akan menurunkan konsentrasi maksimum polutan.

\section{DAFTAR PUSTAKA}

ASME, 1968. Recommended Guide for Prediction of the Dispersion of Airborne Effluents. Second Edition. New York.

Boas, M. L. 1983. Mathematical Methods in the Physical Sciences. Second Edition. John Wiley and Sons, Inc., USA.

Csanady, G. T. 1973. Turbulent Diffusion in The Environment. D. Riedel Publishing company. Dordrecht. Holland.

Fardiaz, S. 1992. Polusi Air dan Udara. Kanisius. Yogyakarta.

Fischer, H. B., E. G. List., R. c. Y. Koh., J. Imberger and N. H. Brooks. 1979. Mixing in Inland and coastal Waters. Academic Press. New York.

Rao, M. N. 1983. Air Pollution. Third Edition. Tata-McGraw Hill. New Delhi.

Socolofsky, J. A., and G. H. Jirka. 2002. Environmental Fluid Mechanics : Mass Transfer and Diffusion. Second Edition. Universitat Karlsruhe, Germany. 
